EASTERN REVIEW 2017, T. 6

Anna Fligel

\title{
Diversity in unity? Some remarks on Europe in the light of Shmuel N. Eisenstadt's theory of multiple modernities
}

I found the inspiration for treating the category of diversity as the keystone of thinking about Europe in the historical sociology of Shmuel N. Eisenstadt, in particular in his concept of multiple modernities. Thus, the crucial point of reference here will be precisely this theory. Also, inspired by Eisenstadt, I am going to adopt an interdisciplinary approach, in particular in terms of drawing from the results of research of such disciplines as sociology, history, but also political sciences and international relations studies. That said, the main domain of my research is political philosophy and also social ethics, therefore, the present reflections are primarily focusing on philosophical and theoretical issues.

The theory of multiple modernizations forms a part of the theory of multiple modernities, or it should be rather said that these two theories remain in a relationship of dialectic unity, i.e. they are internally interweaving. Thus, in the first part I am going to present each of them generally and also present the major ideas and concepts bound to them. Then I move on to the issue of history, i.e. I present the origins of the European diversity and will also draw some theoretical conclusions. That said, in the third part (as an example) I will try to show the eventual consequences of the adoption of my research perspective, i.e. the use of the category of diversity as the keystone for the European political system.

\section{Eisenstadt's multiple modernities and the category of diversity}

"Modernization is used when referring to a process which is determined by place and time [it must be very particular, specific-A.F.] and has to be understood as a unique evolutionary direction which leads to a modern cultural and societal 
innovation"1. The theory of Samuel N. Eisenstadt orders us to recognize the plural reality, i.e. multiple modernizations and multiple modernities. This point distinguishes Eisenstadt's theory from the classical theory of modernization. Put precisely, "modernization is not a set of fixed patterns of structural changes", just as we do not have only one model of modern culture.

In the classic sense, ,modernization is the adjustment of the society in a purposeful and planned manner to a recognized model of modernity, the most often to the pattern of some existing society considered modern"3. In the framework of Eisenstadt's theory "changes bound for modernization can have different sources and can also result in various, even divergent understanding of modernity, bearing traces of different cultures, religious systems and traditions"4. Theories of multiple modernities and multiple modernizations emerged from Eisenstadt's research in the field of macro-sociological comparative studies. He started his research from the analysis of the political systems of empires, and these studies led him to a comparative analysis of civilizations ${ }^{5}$. It is worth noticing, that this is not an enumeration of historical events, but a multi-dimensional theoretical description of the structural changes.

Complementary to the theory of multiple modernity is the theory of axial civilizations and the first axial era. I need to mention it, because according to Eisenstadt, the phenomenon of multiple axial civilizations, i.e. pre-modern civilizations, constitutes an important factor of the later emergence of various types of modernities. The Classical axial era is the time from 6th $\mathrm{BC}$ to 1 st $\mathrm{AD}$. At this time there were formed, largely autonomously and in different parts of the world, new ontological visions. Their epicenter was the concept of the gap between the transcendent world and the earthly domain and the requirement to subordinate everything to the transcendent one. (It should be noted, however, that the axial civilizations, in spite of these general characteristic common features, had great differences) $)^{6}$. The axial era as such lasted at least until the twelfth century, and

${ }^{1}$ G. Preyer, The Perspective of Multiple Modernities On Shmuel N. Eisenstadt's Sociology, „Theory and Society. Journal of Political and Moral Theory” 2012, vol. 4, p. 27, http://www.fb03. uni-frankfurt.de/48846515/GPreyer_Eisenstadt_Multiple_Modernities.pdf (28.04.2016).

2 Ibidem, p. 29.

3 P. Sztompka, Socjologia, Kraków 2002, p. 508.

${ }^{4}$ A. Ostolski, Wprowadzenie, [in:] S.N. Eisenstadt, Utopia i nowoczesność. Porównawcza analiza cywilizacji, Warszawa 2009, p. 27-28.

5 Ibidem, p. 29.

${ }^{6}$ This difference - as Manussos Marangudakis recognizes - consists in "greatly on the particular way they understand 'salvation': to put it simply, Judaic 'obedience', Greek 'truth', Confucian 'harmony', Buddhist 'detachment', Hindu 'purification', Christian 'redemption' and Muslim 'submission' differ greatly both in ontological terms and behavioral effects. The specific orientation of salvation (this-, other-, or a combination of this- and otherworldliness) in general, and the various structuration processes of the particular institutionalizations of these ontological maps, 
even up to the seventeenth century. That century, according to Eisenstadt, initiates the second axial era, i.e. the era of multiple modernities. The time span between the twelfth and seventeenth century should be treated essentially as a transition period. Then the importance of the great visions of ontological gap begun to break down, and finally, in the seventeenth century, their collapse took place which was definite and fundamental, but not however complete.

To a significant extent, the relationship between the axial civilizations and modernity has been re-systematized by Eisenstadt. Comparative studies led him to conclude that modernity is not something uniform and homogeneous just as it is not something that emerges in a simple way from the European axial civilization. It is not like that, because modernization began as a structural differentiation. Furthermore, the processes of structural differentiation are the key component of modern evolution. There are three aspects or dimensions of society: structural, institutional and cultural that combine together in many different ways within various and numerous historical constellations and contexts. Thus, there are multiple modernities and multiple modernizations ${ }^{7}$.

What I have said up to now, has as its reference the global level and it is - as I have also already mentioned - the result of the comparative studies of civilizations. However, Eisenstadt's theory is not limited only to the widest global perspective, as we can see both explicitly in the texts of Eisenstadt and in the latest interpretations of his theory. By way of an example, I would like to refer briefly to the results of research of Werner Krawietz in the field of comparative analysis of European legal systems ${ }^{8}$.

In his research, following Eisenstadt, Krawietz emphasizes that "we have evidence that modernization does not lead to unification and convergence of social structures and legal systems". Modernization consists in differentiations, therefore, ,continuously modifies our belief systems, our legal systems and their implementation in a process of social interaction and transformation"10. Just by comparing the legal systems of central and western Europe as well as eastern, according to him one can evidently observe that we have many different legal systems and numerous types of modernizations of these systems.

have deepened this basic distinctiveness and created a large variety of 'traditionalisms' that need to be examined and analyzed as distinct social systems, rather than as many cases of "premodernity", M. Marangudakis, Multiple Modernities and the Theory of Indeterminacy, [in:] Varieties of Multiple Modernities. New Research Design, eds G. Preyer, M. Sussman, "International Comparative Social Studies" 2016, vol. 33, p. 63.

7 S.N. Eisenstadt, Utopia ..., p. 383-384.

8 W. Krawietz, Multiple Modernities in Modern Law and Legal Systems: Shmuel Eisenstadt's Grand Design and Beyond, [in:] Varieties..., p. 90-108.

${ }^{9}$ Ibidem, p. 91.

${ }^{10}$ Ibidem. 
To indicate the causes of this diversity, Krawietz stresses that there is a variety of informal social conditions and so-called social preconditions that play an important role during the process of formulating the law. The author distinguishes, among others, between national legal systems and non-state systems. Additionally he distinguishes - which is at this point more important - between formal law and informal one. And he emphasizes that "law does not, however, only come into existence in specific bodies set up by the state or in highly bureaucratized states with their legal staffs" 11 but also by a various informal societal preconditions mentioned above. "The state has neither a monopoly, nor a prerogative for the creation of law, but only a normative-functional authority and superiority"12. This approach Krawietz called a New Paradigm of Theorizing about Law ${ }^{13}$. A very similar approach is presented by the representatives of so-called new legal pluralism (R. Kohen, D. Zolo, S. Berman).

In summary, it can be said that in comparative analysis of civilization, on the one hand, and of legal systems, on the other hand, from both emerge and distinguish the category of diversity. There are many different modernizations, many different modernities, as well as many different legal systems, political systems, and also collective identities. This refers simultaneously to the global scale, as well as to the scale of lower levels, starting with the regional (i.e. macroregional) via the state level and ending on the micro-regional scale. The concept of diversity in this regard could be essentially interchanged with the concept of pluralism, as, for example, it was done based on the theory of law and expressed explicitly in the name of new legal pluralism.

At this stage, the category of diversity interests me primarily as a key, or at least as an important concept for the modernizing societies that have much in common, yet seriously differ among themselves" ${ }^{14}$. At this point an important question to be presented to Eisenstadt is: what is the real and profound reason for this diversity? Well, according to the Israeli sociologist it is the very nature of social evolution or social change, and is called by him as a socio-structural change. According to him, social change is not a natural event nor something caused by ontologies dominating within a certain civilization nor solely by the very social structure. It is rather the result of the interweaving of the cultural and socio-structural dimensions in the concrete situation ${ }^{15}$. In addition, sociostructural change always simultaneously consists in the transformation of the order as well as the partial maintenance of it. Anyway, the fundamental feature of the socio-structural change is an internal indeterminacy of the process of societal

\footnotetext{
${ }^{11}$ Ibidem, p. 92.

12 Ibidem.

13 Ibidem, p. 104.

${ }^{14}$ S.N. Eisenstadt, Utopia ..., p. 385-386.

${ }^{15}$ Ibidem, p. 57.
} 
communication and the awareness of this indeterminacy. The point is that any interactions (between actors, aims etc.) are always something indeterminate, therefore, they are always open, i.e. there is within them a permanent possibility of continuous change ${ }^{16}$. These qualities of indeterminacy and openness of social interactions are - according to this theory - derivatives of something even deeper, i.e. of a biological human program, which is primarily characterized precisely by openness ${ }^{17}$. It is a concept that Eisenstadt drew from E. Meyer ${ }^{18}$.

The concept of Eisenstadt is the so called cultural theory of development and change. In Eisenstadt can be found a synthetic and illustrative definition: "Any specific pattern of change needs to be [...] understood as a combination of historical contingency, structure and culture" 19 . The contingency and indeterminacy are bound to an openness of human biological program.

What I consider to be a fixed component and dimension of Eisenstadt's theory are therefore the categories of diversity and change. His research is usually classified as historical sociology. Presently, I am going to briefly supply them with some reflections of historians, however, this time I will focus on a significantly more specific issue, i.e. on the issue of European collective identity.

${ }^{16}$ Zob. G. Preyer, The Perspective..., p. 9. We can additionally read in Eisenstadt: "The existence - in all areas of human action - of open spaces between the general propensities of human beings and the concrete specifications of these propensities means that the crux of concrete human activity is the 'filling in' of such spaces. Such 'filling in' can be effected only through social interaction, which however, is also characterized by indeterminacies and open spaces, which begins with the processes of the socialization of the young and continues through the adult life of members of societies", S.N. Eisenstadt, Power, Trust, and Meaning: Essays in Sociological Theory and Analysis, Chicago 1995, p. 331.

${ }^{17}$ Furthermore, we read: "A basic derivative of the openness of the human biological program, as many "philosophical anthropologists, including A. Portman, A. Geglen and Helmut Plessner have indicated, is the existence of very wide, indeterminate spaces between the general capacities of human beings, rooted in their biological characteristics, including the capacity for language acquisition and use, tool making, social interaction, etc. This also includes the concrete specification of these capacities or potentialities such as learning how to speak a language, creating a specific technology, and so on.

It is the indeterminacy inherent in all areas of human activities that makes human beings 'programed for culture' - to use Clifford Geertz's felicitous expression. Yet, here again, human beings are programmed for culture in general, and not for any specific culture, for language in general and not for any specific language, for social division of labor in general - and not for any specific type of such division of labor". S.N. Eisenstadt, Power..., p. 330-331.

${ }^{18}$ E. Meyer, Evolution and the Diversity of Life, Cambridge 1976.

${ }^{19}$ S.N. Eisenstadt, Utopia ..., p. 57. 


\section{European collective identity and diversity}

To paraphrase the words of the German historian Michael Borgolte one could say: "apart from the lack of political unity the most stable feature of Europe has always been diversity" 20 . Speaking about the diversity of Europe means here still thinking about cultural, political, and legal diversity simultaneously. According to, for example, N. Davis, Europe, both historical and contemporary, actually consists in non-identity. Thus, in his opinion, it must be held that every European country is different from any other, but even in the western Europe we can observe deep differences ${ }^{21}$. This is compatible with the paradigm created by Eisenstadt.

The roots of this diversity should be traced back to the early Middle Ages, and even to Late Antiquity. Borgolte, but also other historians of the Middle Ages, advocates the belief that this period in the history of our continent is characterized by a multiplicity of cultures. Following Ernst Pitz, he recognizes that one cannot talk about the period from $3^{\text {rd }}$ to $13^{\text {th }}$ century as a time of Christian unity. From the early Middle Ages the space of the Mediterranean, from the Atlantic to the Indian Ocean, was characterized by breakdown. Firstly, it was split into the East and Byzantium, then into Greek Christianity and areas subordinated to Muslims. Therefore Borgolte claimed that the Middle Ages were the period remaining under the influence of monotheistic religions, among which there were Western Christianity, Orthodoxy and Islam, although Judaism must be indicated as well. Eisenstadt calls this period a time of great axial civilizations, because he considers the indicated cultures as separate, i.e. essentially different civilizations, which in the European area truly co-existed and entered into various interactions with one another. Borgolte moreover adds that although "they competed with each other for the Mediterranean, they were still able to maintain their former unity, through common roots in the Greco-Roman world. As Pitz suggested, this thesis also refers to the present"22.

So, the indicated historians fully subscribe to the thesis that "the Latin-centric idea of the unity of medieval Europe in given perspective is unsustainable"23. In conclusion it is worth referring to the words of Edgar Morin who "claimed that thinking 'Europe' means to consider her as a complex creation, which unites in herself the biggest differences and inseparable contradictions" ${ }^{\prime 2}$.

${ }^{20}$ M. Borgolte, Jak Europa stała się różnorodna. O średniowiecznych korzeniach różnorodności aksjologicznej, [in:] Kulturowe wartości Europy, eds H. Joas, K. Weigandt, Warszawa 2012, p. 104.

${ }^{21}$ N. Davis, Europe: A History, Oxford-New York 1997, p. 215.

${ }^{22}$ M. Borgolte, Jak Europa..., p. 96.

${ }^{23}$ Ibidem, p. 100.

${ }^{24}$ E. Morin, Penser Europa denken, Frankfurt-New York 1991, p. 19, quote for M. Borgolte, Jak Europa ..., p. 14. 
It is worth noting, as I have already mentioned, that Eisenstadt infers from his empirical and critical study of the axial civilizations that these civilizations were characterized by great diversity within themselves. Furthermore he argued that this diversity "contributed to the emergence within these civilizations of the open spaces, which could give the opportunity to develop of various combinations and greater autonomy of primitive, 'ethnic', regional and political communities"25.

Hence, as I think, from Eisenstadt's considerations can be derived a general relationship, fundamentally regarding the axial civilizations, however, it may have a considerable significance for contemporaneity. This relationship applies to the following indicated attributes: diversity - openness - autonomy. It would sound as follows: together with great diversity must go hand in hand the creation of open spaces, together with them must go hand in hand the creation of greater autonomy (the growth of self-awareness), therefore, the impossibility of monopolization. In other words, diversity and its associated openness and increased autonomy cause the impossibility of the monopolization of all these elements and various communities by any single factor. I understand the open spaces in this context foremost as open possibilities. The point is that, where there is a large variety of social life, the elements of that diversity must enter in various interactions between themselves. Next, the last phenomenon must cause the emergence of numerous new possibilities (i.e. these open spaces). And along with gaining awareness of these opportunities, the degree of autonomy must necessarily increase and, simultaneously, the impossibility of monopolization.

One can derive from these considerations a further conclusion. If one accepts that great diversity is a constant or better to say a permanent feature of the European space, already from the beginning of her history up to this day, and furthermore, if one accepts the relationship derived from Eisenstadt (between diversity - openness - autonomy), therefore it becomes possible siding with the three following ideas. Firstly, siding with the concept according to which diversity, not only cultural but also political and legal, is a value. Secondly, siding with the rule of equality in diversity ${ }^{26}$. And thirdly, connected to the second point, siding with the replacement of the principle of unity in diversity by the principle of diversity in unity.

Concerning the issue of equality in diversity, it consists foremost of the principle of equal opportunities for all the members of a given society, however from the perspective of contemporaneity, it actually consists of raising this idea to the next, higher level. It is known that the principle of equal opportunities, just after its theoretical elaboration in different ways and to varying degrees by John Rawls in his Theory of Justice (1972), started to be implemented in many Western societies.

${ }^{25}$ S.N. Eisenstadt, Utopia ..., p. 78.

${ }^{26}$ W. Reinhard, Afirmacja zwyczajnego życia, [in:] Kulturowe..., p. 212. 
Nowadays it is a regular part of so-called social policy of probably all countries of, for example, the European Union, but not only. Nonetheless, its application and its proper understanding still constitute a great challenge, especially because of a huge dynamic of changes that can be continually observed. That is why I stated above that this idea requires rising to the next higher level. Regarding the idea of equality in diversity something else is considered, i.e. the attempt to re-define the notion of assimilation. It is about the formulation of such a concept of assimilation which would be able to meet both the requirements of cultural diversity, including legal diversity of migrants, and simultaneously the cultural and legal requirements that exist in the public sphere where the assimilation is going to be realized. This question remains difficult to resolve within the European space interested me here particularly. Assimilation is mostly, and for years was understood, as "adapting to the life in a foreign group through the acquisition of its culture and mastering of the specific properties of the given group" 27 . So, to meet the requirements of the principle of equality in diversity, it would be important to formulate a partially new, much more dialectic concept of assimilation. Without a doubt, the prerequisites here would be openness to dialogue and the ability to diversify the legal system. And as the starting point this should be undertaken mainly by philosophers of law.

Regarding the third issue, i.e. the replacement of the principle of unity in diversity by the principle of diversity in unity, at the moment I mean here mainly (however, I emphasise that not only) the rhetorical perspective, i.e. the mode of expressing which would consist in the change of accent. It is well known that the European Union since the dawn of its history is accompanied by the idea of unity in diversity. One can say that this concept, along with other great ideas, has constituted the ideological foundations of this international institution. The unity of Europe is still a big challenge for her, and simultaneously the indispensable condition of her present and future existence. However, if we really understand the fact that the EU is still a work in progress (and only in a small degree something completed), particularly in the perspective of crises that have seriously torn her in recent years, and furthermore, if we accept the research results of Eisenstadt's sociology expressed in the theory of multiple modernities, perhaps it is high time to place the accent on the issue of diversity, thus, the idea of diversity in unity. Changing the location of terms in the expression does not change the essence of the idea, because, as I think, in principle it cannot be done. Only the accent has been modified, and that would eventually be highlighted even more. Therefore it was emphasized that actually, at least for the moment, it would primarily involve the rhetorical plane. Ultimately, however, it also always considers the actual state of affairs, in this case, it means we need to give justice to the fact of diversity, but simultaneously we need to meet the requirement of unity.

${ }^{27}$ Stownik języka polskiego PWN, http://sjp.pwn.pl/sjp/asymilacja;2441680.html (09.04.2016). 
Of course, if we wish to uphold the category of diversity and the aforementioned principles as the essential points of reference, also as the research perspectives, it would bring with it a number of the most diverse consequences. It precisely means that these consequences should be analysed separately for the particular spheres of social, political and legal life. As an example, I will now try to answer briefly the question, what might it mean adopting the category of diversity and the aforementioned principles as a research perspective for the political system of the European Union.

\section{Which democracy for Europe?}

If we accept, in accordance with the above mentioned considerations, that the states, nations, communities included in, in this case, the European Union (as well as those which aspire to enter), are profoundly different from each other on many levels (not only on the cultural and ethnic level, but also with regard to the political systems and legal order, as a result of the nature of structural and social evolutionary processes); then, the diversity and the equality in diversity in relation to the European political system should be understood as it was indicated by the forerunners and creators of the European Union, among others, Jean Monnet. They used to speak in relation to the forming bodies - citing the words of Krzysztof Pomian and Elie Barnavi - much about democracy, democratic institutions "which are to realize their sovereignty in the actual political activities, ensuring the inclusion of common interests and their durability" 28 . Actually, they used to speak about the formation "of the first in the history a democratic empire, that is not built on the domination of one nation and the ambition of one person, but of the free will of the people who decided to join with her"29.

It is naturally a very general determinant. However, it seems to touch the bottom of what is most important, especially if we focus on the central element of the last quotation, i.e. the issue of the free will of nations.

To speak more specifically, the modernization of the political system of the EU, taking into account the research perspective based on Eisenstadt's research, should first and foremost rely on her genuine democratization. This should be a multi-level democracy, since we understand the principle of free will of the people in the sense of equality in diversity. In more detail, this time I would like to refer to the words of Gerhard Preyer, who recognizes that: "Clearly stated objective of the democratization of the European Union should consist in supporting the pluralistic multilevel democracy, oriented on subsidiarity, that would replace the

\footnotetext{
${ }^{28}$ K. Pomian, E. Barnavi, Rewolucja Europejska 1945-2007, Warszawa 2011, p. 67.

${ }^{29}$ Ibidem, p. 68.
} 
opinion-representative democracy. Only this could mean the democratization of the European Union" ${ }^{30}$. It should be immediately added that it is impossible to develop this model, remaining in the paradigm of national representative democracy.

Multi-level democracy (MLD) implies participation in democratic procedures, both at the regional, local, national and supranational levels ${ }^{31}$. Hence, it is clear that it is primarily about the diversification of the system; somewhat based on - by analogy - the spheres of justice of M. Walzer and A. MacIntyre ${ }^{32}$. They claimed that contemporary society is very complex and operates on many different levels. Hence, according to them, there are in social life many spheres of reference, and consequently, there should be formed different principles of justice, appropriate for a given sphere. It is without a doubt a far more demanding concept than, for example, theories a la Rawls, where one wants to get things done, e.g. adopting one or two principles of justice. Simply put, we can say that, according to these communitarian philosophers, justice does not merely mean equality for everybody, or to each according to their needs, or to all according to their merit, as it also does not exclude any of these principles. Instead, it means the adoption of each of them, as well as eventually of any other principles adequate to a given sphere of social life, even differentiated for various social groups. This concept could be called a diversified system of justice. In principle, it wants to answer the fundamental feature of the contemporary societies, i.e. their enormous variety and complexity.

Analogically, the diversified system of multi-level democracy in the context of the European Union would be an equally difficult challenge. Someone could even make an allegation that it would be a backbreaking difficult enterprise. Perhaps it would be true, e.g. if one would accept an assumption (although a nonsensical one) that the diversification process would not have a sharply defined area, which could mean that it has to go on ad infinitum. But supposing that this application of the system of multi-level democracy to the different spheres of life would have very concrete limits that would have been agreed upon with consensus, and in addition its implementation process would be spread over a longer period of time, then the objection to a possibly backbreaking endeavour does not seem to be justified. Of course, the elaboration of all the specific issues would be mainly the task of political scientists, lawyers, and not philosophers. In principle, the political philosopher deals with issues on the general plane, she/he is to answer

${ }^{30}$ G. Preyer, Tożsamość zbiorowa Europy $i$ jej integracja polityczna, http://academicon. $\mathrm{pl} /$ serwisy/politologia/aktualnosci/artykuly_online/tozsamosc-zbiorowa-europy-i-jej-integracja (09.04.2017).

${ }^{31}$ M. Żurek, Próba klasyfikacji i typologii podejścia Multi-level Governance, [in:] Multi-level governance w Unii Europejskiej, eds J. Ruszkowski, L. Wojnicz, Szczecin-Warszawa 2013, p. 102.

${ }^{32}$ Por. M. Walzer, Spheres of Justice. A Defense of Pluralism and Equality, New York 1983; A. MacIntyre, Afetr Value, Notre Dame 1984. 
the question why of a certain concept, to identify the key determinants of a model or pattern, to provide its justification.

Undoubtedly another matter of a great importance is the need to link this multi-level model of democracy with the principle of subsidiarity. This principle generally holds that if something can be accomplished at a lower level, it should be accomplished right there ${ }^{33}$. Sometimes this principle is expressed in the following sentence: As much power as necessary, as much freedom as possible. In the institutional situation currently dominating the EU, the implementation of the specified rule has to link with the strengthening of all of the forces in the Union's institutions that counteract centralization. In this regard Gerhard Preyer added another condition: "legitimacy should not be based only on political representation, but also must be supported by the mutual control of political bodies, through strong courts and decentralization" 34 .

All of this must go hand in hand with the development of civil society. The relationship between democracy and civil society is double-sided and by the definition is not to be undermined. Simplest put, it means that one cannot talk about a democratic political system without referring to a civil society and vice versa. And the fact that understanding of these ideas throughout history underwent transformations does not matter here, due to the fact that, in essence, they did not really change at all ${ }^{35}$. Yet in other words, civic spirit enables democratic politics, and democracy and only democracy is able to create a civil society. Thus, democracy requires open doors and spaces for various activities within civil society. As it requires a free debate about public affairs, therefore it calls for pluralism of views and opinions ${ }^{36}$. Actually, a test for a democratic political system is its ability to uphold this type of participation ${ }^{37}$.

In the context of the European Union, which particularly interests me here, the indicated theses seem to have a great validity. One could even hypothesize, and it would not be a new idea, that the EU democracy deficits are largely the result of the lack of active participation of the EU citizens in the decision-making processes $^{38}$, i.e. of the actual lack of a developed civil society. Furthermore, in the perspective of multi-level democracy presented above, which focuses on the

${ }^{33}$ Ibidem, p. 82.

${ }^{34}$ Por. G. Preyer, Kollektive Identität Europas und seine politische Integration, "Rechtstheorie" 2014,no. 4,pp. 507-515; http://ejournals.duncker-humblot.de/doi/abs/10.3790/rth.45.4.507(08.04.2016).

${ }^{35}$ Por. D. Pietrzyk-Reeves, Idea spoleczeństwa obywatelskiego. Współczesna debata i jej źródła, Wrocław 2004; B. Brugger, Republican Tradition in Political Thought: Virtuous or Virtual?, New York 1999; R. Dagger, Civic Virtues: Rights, Citizenship and Republican Liberalism, Oxford 1997.

${ }^{36}$ K. Orzeszyna, Społeczeństwo obywatelskie w Unii Europejskiej, ,Teka Komisji Prawniczej”, Warszawa 2009, p. 101, https://www.mpips.gov.pl/spoleczenstwo-obywatelskie/spoleczenstwoobywatelskie-w-unii-europejskiej/ (09.04.2016).

${ }^{37}$ Ibidem.

${ }^{38}$ Ibidem, p. 107. 
diversification of the system, the development of civil society seems to be one of its necessary conditions, especially if we accept the principle of subsidiarity. The case is even more obvious, if we define the civil society as "a manifestation of a bottom-up activity of independent citizens, who contribute to both an optimal formation of life and sustainable development of the EU'39.

To a large extent, it is the European Economic and Social Committee that profoundly understood these issues, however, as it seems, only since 1999. In that year, this advisory body of the EU published a document entitled The role and contribution of civil society organisations in the building of Europe ${ }^{40}$. This document includes an in-depth analysis of the very concept of civil society but it also presents the Committee as a body wanting to represent this society. After this document, there were created a few other opinions and documents important for this topic. Especially important in this regard was the draft of the EU Constitution, in which there was an explicated talk about a participatory democracy. However, as it is well known, this Constitution has not entered into force. The Lisbon Treaty (art. 10 and 11) takes over certain provisions of that draft Constitution, which refers to the role and powers of civil society (however, it omits any idea of participatory democracy). But these documents are not influential enough to be able to state that the importance of European citizens was finally really appreciated and adequately validated.

It is noteworthy, that in view to the implementation and development of multi-level democracy and also the essential factor in the form of civil society, the existence of the already developed information and communication technologies is an undoubted advantage of our times. In this regard, again thanks to the European Economic and Social Committee, last year (2015) there was published Opinion on Social innovation, networking and digital communication, where we have a clear understanding of the opportunities offered by e.g. Internet in the development of a "more direct democracy" 41 . Nevertheless, there is a long way from understanding into practice. The importance of advanced information and communication technologies for the formation of direct democracy has already

\section{Ibidem.}

40 Por. The Civil Society Organised at European Level. Proceedings of the First Convention, Brussels, 15 and 16 October 1999, http:/www.eesc.europa.eu/resources/docs/actes_sco_en.pdf (08.04.2016).

41 The Opinion was published on August 31th 2015 and we read already in the first two paragraphs: "1.1. Social innovation and collaborative networks must be fully used in order to boost participation by the public and civil society in general in designing and managing EU policies, by means of distributed, collective and bottom-up projects that strengthen more direct democracy. 1.2. Universal access to the new technologies in general, and broad-band internet in particular, must continue to be a priority for the European Union, and it should be seen as a service of general interest that must narrow the digital divide and counter the consequences of the ensuing social exclusion", http://www.eesc.europa.eu/?i=portal.en.ten-opinions.33029 (08.04.2016). 
been found important by numerous academics - at least on the theoretical level. One can find an expression of this in the already developed concepts and theories of e-Democracy, also known as digital democracy ${ }^{42}$.

\section{Concluding thoughts}

At the level of ideas, in this paper the key issue for me was to convey the idea that contemporaneity needs to recognize that diversity is (or ought to be) a value. I have been writing this from the perspective of an understanding of value, according to which - as Wolfgang Reinhard argues - "as for values, it is not about the reality of life as such, but about the meaning that people attribute to it" Simultaneously I accept the definition of Hans Joas, according to which "values are something that 'grab' us, that we cannot directly control, but, at the same time, something that lead us to a specific experience of freedom". Combining these two definitional perspectives, it is necessary to add that value arises or emerges during a long and tedious process.

On a more general level, I have treated the value of diversity as a research category emerging from various perspectives, and therefore having different shades of meaning. In the context of Eisenstadt's thought, the concept of diversity can be understood as the differentiation of the structure of modern societies. It stems from - using technical sociological language - the structural-evolutional process of the differentiation of these societies. Much more specifically, the differentiation of the structure of societies means that these societies are extremely diverse. It regards ethnical and cultural sides and also the range of collective identity, as well as legal and political systems. In the context of Western modernities, it also involves the diversity of individual identities, since one of the most crucial indicators of these modernities is individualism. Individualism by definition accepts the fact that people are inherently different, they have different views on the good life, etc.

In the perspective of contemporary European societies, as the result - generally speaking - of mass migrations in different directions and for different reasons (e.g. European integration, and now also the war in the Middle East) and as the result of deepening globalization processes in many areas, diversity has become an important phenomenon and also the fact that we need to face. On the level of the political system

42 J. Freeman, S. Quirke, Understanding E-Democracy, „Journal of e-Democracy” 2013, vol. 5, no. 2, p. 141-154, http://www.jedem.org/index.php/jedem/article/view/221/182 (08.04.2016).

${ }^{43}$ The author provides as an example human labor, that became value essentially only through Christianity. Before, e.g. in Geek ancient culture, it was actually something lacking in value; W. Reinhard, Afirmacja..., p. 212. 
I recognized - as an example - that the response to this diversity should be siding with multi-level democracy, as being subsidiary and having a foothold in civil society. Especially in the context of the last idea (of civil society), the issue of diversity seems to be a very important one, in this instance the pluralism of world views and cultures. Thus, as it was claimed by Borgolte, "a decisive idea for Europe is 'the principle of dialogue'; its task would be taken as analysis of fruitful confrontations between differences, antagonisms, competitiveness and complementarity" ${ }^{\prime 4}$.

Shmuel N. Eisenstadt via his theory of multiple modernities provides a solidly theoretical but also empirical foundation to make this process of struggle (with the phenomenon of diversity) in some ways facilitated and streamlined. As I have tried to show above, his researches on the topics of the social change and of the structural-evolutional differentiation of modern societies, evidently show that even within the same European area, the diversity must be treated as the result of these processes (hence Eisenstadt derived the idea of multiple modernities). I would like to remind again that this pluralism (occurring on so many levels) is a prerequisite for the formation of open spaces and at the same time it prevents the system from being monopolized by any given factors. This part of the Eisenstadt's analysis provides another argument for the normative thesis that the diversity of the human world is a value. Should it not be recognized that the formation of open spaces and at the same time the prevention of monopolies, are essential conditions to facilitate the emergence of a freer man, and a freer society? Diversity would, therefore, be the condition of freedom. And, especially in the European context, it is not about more and more freedom for man and more and more freedom for societies?

\section{Bibliography}

Borgolte M., Jak Europa stała się różnorodna. O średniowiecznych korzeniach różnorodności aksjologicznej, [in:] Kulturowe wartości Europy, eds H. Joas, K. Weigandt, Warszawa 2012.

Boundon R., Efekt odwrócenia, Warszawa 2008.

Brugger B., Republican Tradition in Political Thought: Virtuous or Virtual?, New York 1999.

Dagger R., Civic Virtues: Rights, Citizenship and Republican Liberalism, Oxford 1997.

Davis N., Europe: A History, Oxford-New York 1997.

Eisenstadt S.N., Power, Trust, and Meaning: Essays in Sociological Theory and Analysis, Chicago 1995.

Eisenstadt S.N., Utopia i nowoczesność. Porównawcza analiza cywilizacji, Warszawa 2009.

Europejski Komitet Ekonomiczno-Społeczny, Opinion of the Committee of 22 September 1999, The role and contribution of civil society organizations to the building of Europe, http://www.eesc.europa.eu/resources/docs/actes_sco_en.pdf (08.04.2016).

${ }^{44}$ M. Borgolte, Jak Europa ..., p. 104. 
Europejski Komitet Ekonomiczno-Społeczny, Opinia w sprawie innowacji społecznych, sieci i komunikacji cyfrowej, z dn. 16 września 2015 r, https://webapi.eesc.europa. eu/documentsanonymous/EESC-2014-04902-00-00-AC-TRA-pl.docx (08.04.2016).

Freeman J., Quirke S., Understanding E-Democracy, "Journal of e-Democracy" 2013.

Krawietz W., Multiple modernities in modern law and legal systems: Shmuel Eisenstadt's grand design and beyond, [in:] Varieties of Multiple Modernities. New Research Design, eds G. Preyer, M. Sussman, "International Comparative Social Studies" 2016, no. 33.

MacIntyre A., Afetr Value, Notre Dame 1984.

Marangudakis M., Multiple Modernities and the Theory of Indeterminacy, [in:] Varieties of Multiple Modernities. New Research Design, eds G. Preyer, M. Sussman, "International Comparative Social Studies" 2016, no. 33.

Meyer E., Evolution and the Diversity of Life, Cambridge 1976.

Morin E., Europa denken, Frankfurt-New York 1991.

Orzeszyna K., Społeczeństwo obywatelskie w Unii Europejskiej, Teka Komisji Prawniczej", Warszawa 2009.

Ostolski A., Wprowadzenie do: S.N. Eisenstadta, Utopia i nowoczesność. Porównawcza analiza cywilizacji, Warszawa 2009.

Pietrzyk-Reeves D., Idea społeczeństwa obywatelskiego. Współczesna debata i jej źródła, Wrocław 2004.

Pomian K., Barnavi E., Rewolucja Europejska 1945-2007, Warszawa 2011.

Preyer G., Kollektive Identität Europas und seine politische Integration, "Rechtstheorie" 2014, Nr 4(45).

Preyer G., The Perspective of Multiple Modernities On Shmuel N. Eisenstadt's Sociology, "Theory and Society. Journal of Political and Moral Theory" 2013, no. 30.

Reinhard W., Afirmacja zwyczajnego życia, [in:] Kulturowe wartości Europy, eds H. Joas, K. Weigandt, Warszawa 2012.

Sztompka P., Socjologia, Kraków 2002.

Walzer M., Spheres of Justice. A Defense of Pluralism and Equality, New York 1983.

Wojnicz L., Multi-level governance w Unii Europejskiej, Szczecin-Warszawa 2013.

Żurek M., Próba klasyfikacji i typologii podejścia Multi-level Governance, [in:] Multi -level governance w Unii Europejskiej, eds J. Ruszkowski, L. Wojnicz, SzczecinWarszawa 2013.

Anna Fligel

\section{Różnorodność w jedności? Uwagi na temat Europy w świetle teorii Shmuela N. Eisenstadta wielości nowoczesności}

Artykuł stanowi przyczynek do dyskusji na temat Europy z wykorzystaniem takich pojęć jak różnorodność i wielość. Odwołuje się do teorii Shmuela N. Eisenstadta wielości nowoczesności. Celem artykułu jest teoretyczne i historyczne uzasadnienie stosowania 
tych pojęć w odniesieniu do definiowania Europy. Ma on zarazem charakter wielowątkowy, jego szeroki zakres problemowy jest uzasadniony m.in. względami filozoficznymi i politologicznymi: zbiorowej tożsamości Europy, jej systemu politycznego i potencjalnych kierunków jej modernizacji. Autorka przyjmuje, iż Europa jako Unia Europejska jest wciąż konstrukcją $\mathrm{w}$ procesie i tylko w ograniczonym stopniu może być uznana za coś kompletnego. Tym bardziej, że w ciągu ostatnich kilku lat wydarzenia o zasięgu globalnym, jak upadek żelaznej kurtyny w roku 1989, atak na Centrum Handlu Światowego w roku 2001 czy kryzys finansowy z roku 2008, pośrednio wpływają na jej kondycję. Niektóre kryzysy jak chociażby kryzys migracyjny mają na nią wpływ bezpośredni.

Słowa kluczowe: demokracja, Europa, teoria wielości nowoczesności, Eisenstadt, Unia Europejska.

Анна Флигел

\section{Разнообразие в единстве? Замечания на тему Европы через призму теории множественности современности Шмуеля Н. Эйнштадта}

Статья вносит свой вклад в дискуссию на тему Европы с использованием таких понятий, как разнообразие и множественность, отсылая к теории множественности современности Шмуеля Н. Эйнштадта. Целью статьи является теоритическое и историческое обоснование использования этих понятий по отношению к дефинированию Европы. Статья обладает многогранным характером, а ее широкий проблемный спектр обусловлен, в том числе, с философской и политологической точки зрения, коллективным самоопределением Европы, ее политической системой и потенциальными направлениями ее модернизации. Автор принимает, то Европа как Европейский союз, все еще, является явлением в процессе и только в ограниченной степени может быть признана чем-то завершенным. Тем более, что в течение нескольких последних лет события глобального масштаба, такие как падение железного занавеса в 1989 году, террористическая атака на Международный торговый центр в 2001 году или мировой финансовый кризис в 2008 году, косвенно влияют на ее состояние. Некоторые кризисные ситуации, как хотя бы миграционный кризис, имеют на нее непосредственное влияние.

Ключевые слова: демократия, Европа, теория множественности современности, Эйнштадт, Европейский союз. 